\title{
SEDIMENT YIELD PREDICTION IN TANZANIA: CASE STUDY OF DODOMA DISTRICT CATCHMENTS
}

\author{
Mathew K. Mulemgera \\ Department of Agricultural Engineering \& Land Planning, \\ P. O. Box 3003, Chuo Kikuu, Morogoro, Tanzania \\ E-mail: Mulengera@yahoo.com
}

\begin{abstract}
Soil erosion and sedimentation is serious and is resulting in rapid sedimentation of streams and reservoirs in Tanzania. This makes sediment yield modeling important before undertaking water resources development projects, although it has so far not been done in the country. At present sediment yield prediction can be done using physically based models, empirical soil erosion and sediment yield models, and sediment rating curves. The physically based models contain numerous parameters that are difficult to measure or estimate, making them inappropriate in developing countries like Tanzania. The rating curves give rough estimates while the empirical sediment yield models need runoff data that is not available in Tanzania. The revised USLE parametric (empirical) model that had been tested and found to be suitable for soil erosion prediction was selected for sediment yield prediction study reported in this paper.
\end{abstract}

The testing of the model has shown to give acceptable results. For sediment measurements ranging from about 7 t/ha.year to 11 t/ha.year, the model predicted sediments yields ranging from about 6 t/ha.year to 12 t/ha.year, with coefficent of determination $\left(R^{2}\right)$ equal to about 0.53. Since soil erosion and sedimentation of water resources are serious problems in Tanzania, sediment yield modeling using the RUSLE can be a very useful tool in the country when used.

Keywords: Soil erosion, catchment sediment yield, empirical models, physically based models

\section{INTRODUCTION}

Soil erosion is a serious problem in Tanzania, especially in the central semi-arid areas in which the study area (Dodoma district) is located (see Fig. 1)(Christiansson, 1981). Soil erosion in the central semi-arid areas is caused by heavy grazing, high and increasing firewood and charcoal demands, and shortage of land that is suitable for cultivation. This erosion results in increased sediment loads in streams and rivers, leading to rapid siltation of water reservoirs. Reservoir sedimentation of about $10 \mathrm{t} /$ ha.year are quite common in the central semiarid areas of Tanzania. The rapid siltation of water reservoirs make sediment yield prediction important when new dams are to be built for water impoundment. 


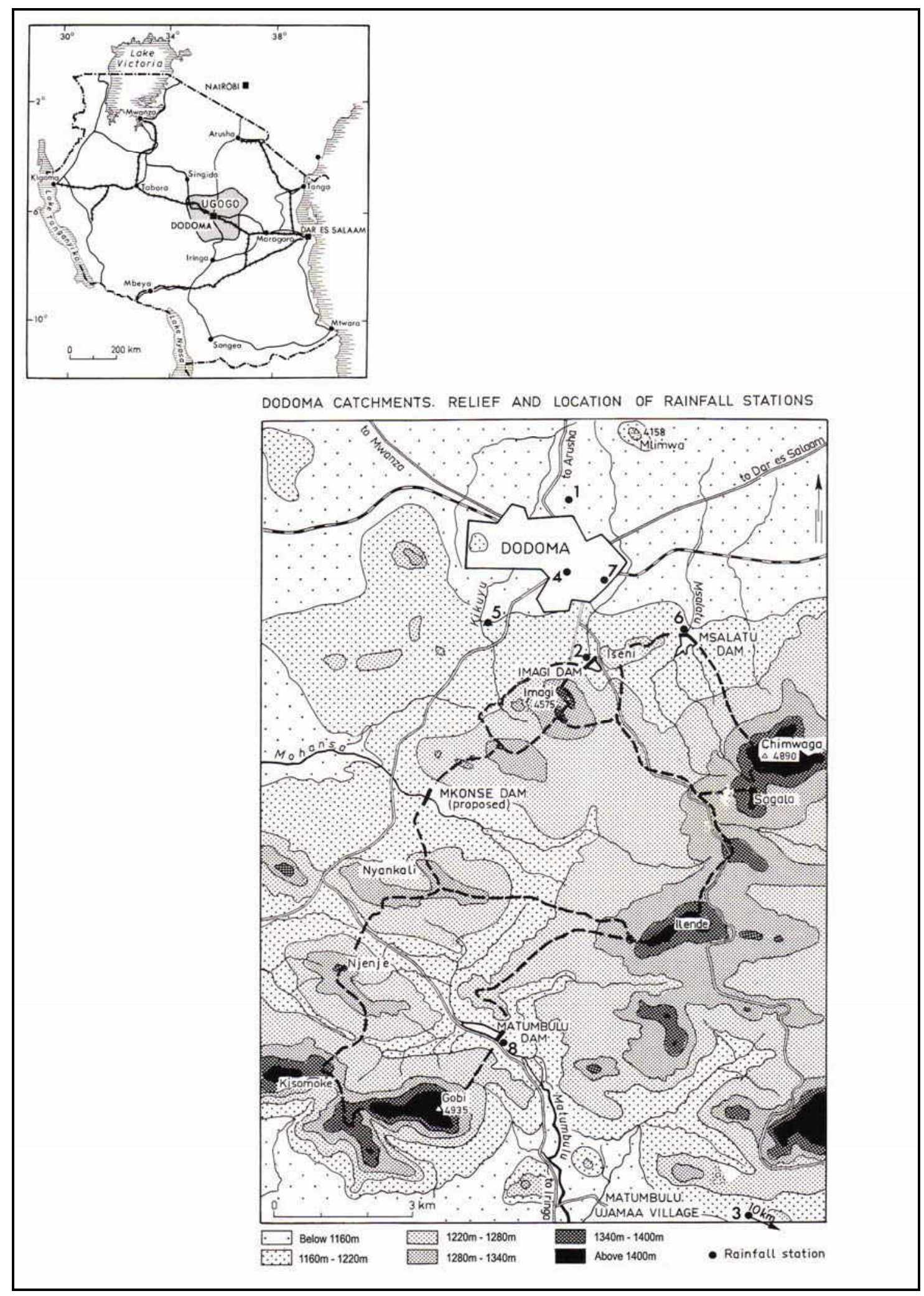

Fig. 1: Dodoma catchments, Relief, drainage and location of rainfall stations 
The study area is characterized by long dry seasons (April to November or December) and short rainy seasons (December to March). Mean annual rainfall in the areas range from $500 \mathrm{~mm}$ to $600 \mathrm{~mm}$ and potential evaporation ranges between $2000 \mathrm{~mm}$ to $2500 \mathrm{~mm}$ per year (Christiansson, 1981).

Topography of the central semi-arid Tanzania is characterized by plains and scattered inselbergs or ridges. The soils appear in catena sequence where the upper slopes of inselbergs have thin stony soils and pediment slopes have red or grey sandy soils. The valley bottoms and flood plains have black and grey deposits. Natural vegetation of dense thicket or miombo woodlands has generally been replaced by semi-natural vegetation of grasses and herbs.

The inhabitants of the study area (Wagogo) are cultivating pastoralists. They mainly practice shifting cultivation where no manure is applied and maintain large herds of cattle, sheep, and goats. Staple crops grown are sorghum and bulrush millet. Maize is also grown on significant areas. The main crops are intercropped with legumes (ground nuts, bambara nuts, cow peas), root crops (cassava, and sweet potatoes), and other crops (water melons, cucumbers, pumpkins, squash, gourds, and calabashes).

\subsection{SEDIMENT YIELD PREDICTION}

Catchment sediment yield research and prediction in Tanzania are very limited. Sedimentation studies have been done for some catchments and basins (Christiansson, 1981; Murray-Rust, 1972; Mulengera, 1996; Rapp et al., 1972; Temple and Sundborg, 1973) for assessing soil erosion in catchment, quantification of water resources siltation, and/or development of sediment rating curves. Thus, despite its importance, so far no sediment yield modeling research has been done in Tanzania, hence the work whose results are reported in this paper.

Four options are available for predicting sediment yields from catchments:-

(i) Using sediment rating curves that have been derived from long term sediment flux and river discharge measurements.

(ii) Making erosion measurements on representative land use areas in a catchment draining to a point that are multiplied by sediment delivery ratio (SDR) for the catchment. (iii) Using sediment yield prediction equation for direct estimates.

(iv) Using soil erosion models.

Rating curves for rivers and streams are not readily available in many developing countries, including Tanzania. Erosion measurements in catchments are expensive, time consuming, thus are not common in the developing countries. Available sediment yield models are statistical models relating rainfall characteristics in the catchment and its topography to sediment yield (Fournier, 1960, and Fleming, 1969 cited in Morgan, 1986), sediment yield curve developed using factors affecting soil erosion and sediment yield data from catchments (Al Kadhimi, 1982), empirical soil erosion models (Renard et al., 1991; Wishmeier and Smith, 1978; Elwell and Stocking, 1982), the modified universal soil erosion equation (MUSLE) (Williams, 1975), and the physically based soil erosion models (Nearing et al., 1989; Morgan, 1994). The equations like those of Fournier (1960) and Fleming (1969) and the sediment yield curve method (Al Kadhimi, 1982) give soil erosion indices, thus are not expected to provide good estimates of sediment yields from catchments. The MUSLE needs runoff discharge and volumes for determining its erosivity. These parameters are not readily available in Tanzania. Thus, the model is not readily applicable in the country. The physically based models include the WEPP (Nearing et al.1989 ) and the EUROSEM (Morgan et al., 1994 ). These equations need data base (e.g. catchment runoff discharges, rainfall intensity, and/or rill and interill soil erodibility) that is not available in Tanzania and other developing countries (Mulengera and Payton, 1999). Therefore, they are not useful under Tanzanian conditions. The available empirical soil erosion models include the (revised) universal soil loss equation $\{(\mathrm{R}) \mathrm{USLE}\}$ (Renard et al., 1991; Wishmeier and Smith, 1978) and the soil loss estimation method for southern Africa (SLEMSA) (Elwell and Stocking (1982). Among the empirical models available only the ( R)USLE is widely used and has been tested and found to be suitable under Tanzania conditions (Mulengera, 1996; Mulengera and Payton, 1999). Thus, this paper evaluates the use of the (R)USLE for predicting sediment yields from catchments in Tanzania based on reservoir sedimentation study done by Christiansson (1981) for the Dodoma District catchments, namely Imagi, Matumbulu, and Msalatu.

There are two approaches of using empirical soil erosion models in predicting sediment yields from watersheds. The first approach involves using the 
sediment delivery ratio (SDR) and modifying the calculation procedure of the model factors in order to transform the catchment into an equivalent plot (Williams and Berndt, 1972). The second approach involves dividing the watershed into morphological areas into which all elementary factors of the selected erosion model can be evaluated (Ferro et. al., 2001). This procedure allows the calculation of soil loss in each morphological area (unit) that is coupled with disaggregated criteria for estimating sediment delivery processes and the unit's SDR to obtain the sediment yield spatial distribution. The disaggregated criteria is determined through measurements of sediment yields from the catchment in question (Ferro et. al., 2001). This approach is not applicable in countries like Tanzania where data on sediment yields from catchments are not available.

The SDR used in the first approach is influenced by a wide range of geomorphological and environmental factors. These include the nature, extent, and location of the sediment sources; relief and slope characteristics; the drainage pattern, and channel conditions; vegetation cover and land use, and soil texture. Developed empirical equations for predicting this parameter show the catchment area to be a dominant control. However, the research results relating the SDR with drainage area have produced a bund of SDR variations for a given catchment area, e.g. for catchment area $\leq 0.01 \mathrm{~km}^{2}$, the SDR has been shown to vary between 0.9 to 1.0 and for catchment area of $1000 \mathrm{~km}^{2}$ it varies between 0.05 and 0.9 (Walling, 1983, cited in Walling, 1988). However, the American Society of Civil Engineers (ASCE, 1975, cited in Walling, 1988) proposed equation one below for estimating the SDR. However, it is important to note that the accuracy of estimated SDR for large catchments using the equation is low.

$S D R=k S^{n}$

Where, $\mathrm{k}$ and $\mathrm{n}$ are constants equal to 0.5 and 0.125 respectively, and

$\mathrm{S}$ is the catchment area $\left(\mathrm{km}^{2}\right)$.

When estimating the sediment yields from catchments using the (R)USLE the soil erodibility, topographic factor, and the cover and conservation factors of the equation need to be transformed to catchment scale (William and Berndt, 1972). The soil erodibility transformation to catchment scale is:-

$$
K=\sum_{i=1}^{n} \frac{K_{i} D A}{D A}
$$

Where, $K_{i}$ is erodibility value for soil ' $\mathrm{i}$ ' in the catchment;

$\mathrm{DA}_{\mathrm{i}}$ is sub-drainage area covered by soil ' $\mathrm{i}$ ';

DA is total catchment (drainage) area, and

$\mathrm{n}$ is the number of soils in the catchment.

The average catchment slope gradient, $\mathrm{s}(\%)$ is obtained as (Williams and Berdt, 1972):-

$$
S=\frac{H\left\{\frac{1}{2}\left(L C_{1}+L C_{n+1}\right)+\sum_{i=1}^{n} L C_{i}\right\}}{D A} x 100
$$

Where, $\mathrm{H}$ is the difference in elevation between contours;

$\mathrm{LC}_{\mathrm{i}}$ is the length of contour " $\mathrm{i}$ " in the catchment, and

$\mathrm{n}$ is the number of areas between contours within the catchment.

Williams and Berndt (1977) proposed to use lengths of contours located at $25 \%, 50 \%$, and 75 $\%$ of the catchment relief resulting into an equation that is simple and easier to use on larger steep catchments.

$s=\frac{0.25 Z\left(L C_{25}+L C_{50}+L C_{75}\right)}{D A} X 100$

Where, $\mathrm{Z}$ is total watershed height,

$\mathrm{LC}_{25}, \mathrm{LC}_{50}$, and $\mathrm{LC}_{75}$ are contour lengths at 25,50 , and 75 percent of $Z$ respectively.

The average catchment slope length, $\lambda$ is determined as:-

$$
\lambda=\frac{L C \times L B}{2 E P_{i} \sqrt{\left(L C^{2}-L B^{2}\right)}}
$$

Where, LC is total length of all contours; 
LB is length of contour base lines touching points on contours that are farthest from the catchment divide;

EP is the number of extreme points on contour (i.e. points where streams or pronounced natural depressions cross contours).

Once the $\mathrm{s}$ and $\lambda$ parameters are determined then the model's equations are used to calculate its topographic

(S and L) factors.

The average cover and conservation practice factor, CP is calculated as:-

$$
C P=\sum_{i=1}^{n} \frac{C_{i j} P_{i} D A_{i}}{D A}
$$

Where, $\mathrm{C}_{\mathrm{ij}}$ is cover factor for month " $\mathrm{j}$ ” for the crop on sub-area "i";

$P_{i}$ is conservation practice factor for subarea "i", and

$\mathrm{n}$ is the number of sub-areas in the catchment.

\subsection{MATERIALS AND METHODS}

\subsection{Location and characteristics of the Dodoma district study catchments}

The Dodoma district study catchments (namely, Imagi, Matumbulu, and the Msalatu) are situated near and on the south of Dodoma Capital City that is on the Dar Es Salaam to Mwanza (lake Victoria) and Kigoma (lake Tanganyika) central railway line (Fig. 1). They are located between latitudes $6^{0}, 6^{\prime}$ and $6^{\circ}, 19^{\prime} \mathrm{S}$ and longitudes $35^{\circ}, 42^{\prime}$ and $36^{\circ}, 14^{\prime} \mathrm{E}$. All the catchments have dams with reservoirs acting as sediment traps. The Imagi catchment area is $2.2 \mathrm{~km}^{2}$ and has steep slopes. It is representative of upper segments of larger drainage basins. On its inselberg slopes vegetation is mainly made of dense thicket and miombo woodland and its pediment slopes are mainly covered by shrubs and sparce grass. The Imagi catchment inselberges are considerably covered by rock and its pediment slopes cover about $46 \%$ of the catchment.
The Matumbulu catchment area is $15 \mathrm{~km}^{2}$. It has steep sided ridge on the south and inselberg hills with steep slopes on the west and undurating low plains on the east. The Matumbulu dam is on the east of the catchment and is situated alongside the Dodoma - Iringa road, $12 \mathrm{~km}$ from Dodoma. As early as 1949 the catchment pediment slopes vegetation was sparse open bush dominated by small shrubs on abandoned fields. Both, cultivation and grazing are dominant on all catchment areas except inslbergs. The studies by Christiansson (1981) discovered that there was little change on land use and erosion in the catchment from 1949 to 1974.

The Msalatu catchment is $8.5 \mathrm{~km}^{2}$ and is drained by several small streams. Its inselberg slopes are mainly covered by dense vegetation. Before the dam was constructed in 1944 dominant uses of the catchment were cultivation and grazing. After completion of dam construction no cultivation was allowed and grazing was limited for a period of 15 years. Since 1960 the conservation measures were abandoned. As a result, vegetation on pediments is of sparse thorn bush and patches of grass with extensive bare surfaces. As for the Imagi catchment, Msalatu catchment consists of inserbergs and relatively steep pediments only. As a result more or less all the eroded soils are transported directly to the reservoir.

\subsection{Determination of the (R)USLE factors}

Research results by Christiansson (1981) and Mulengera (1996) and reconnaissance surveys of the catchments were used to collect all the information needed for sediment yield prediction.

Contour maps for the catchments and equations 3 and 5 were used to calculate the slope steepness and slope lengths for the three catchments. Thereafter the model's slope gradient (S) and slope length (L) factors were calculated using appropriate equations (McCool et al., 1989; Liu et al., 1994). The empirical equation developed by Moore (1979) for East African countries based on long term annual rainfall volume was used to estimate rainfall erosivity values for the catchments. Rainfall records at Dodoma Airport meteorological station were used for the Imagi and Msalatu catchments which are near it and have no long term rainfall records. Rainfall records taken during the sediment measurement period in the Matumbulu catchment that is far from Dodoma were used to determine its rainfall erosivity. 
The De Pauw (1983) soil survey report and the empirical soil erodibility equation developed by Mulengera and Payton (1999) and equation 2 were used to determine the erodibility $(\mathrm{K})$ values for soils found in the catchment.

The cover factor, $\mathrm{C}$ was determined from the land use information records by Christiansson (1981), De Pauw (1983) report and reconnaissance survey made in 2006 for verification of some catchments conditions. Planimeter was used to estimate proportions of different land uses in the catchments that existed during the periods of reservoir sedimentation research. Mpwapwa plots experimental results (Christiansson, 1981) and Hombolo, Dodoma runoff plot studies (Mulengera, 1996) were used to estimate the crop and management factor $(\mathrm{C})$ for cropped field areas. The method proposed by Stocking et al., (1988) was used to estimate cover on grazing areas. The subfactor method by Dissmeyer (1982) was then used to calculate the $\mathrm{C}$ factor values for the grazing areas. The conservation and practice factor, $\mathrm{P}$ in this study was taken to be unity for all the catchments. The $\mathrm{CP}$ value for the entire catchment was then computed using equation 6 .

The sediment delivery ratios (SDRs) for the catchments were obtained from the graph plot of SDR values and drainage areas (Walling, 1983). Then sediment yields $\left(\mathrm{Y}_{\mathrm{s}}\right)$ were calculated as

$$
Y_{s}=S D R \times R \times K \times L S \times C P
$$

Where, $\mathrm{Y}_{\mathrm{s}}=$ sediment yield $(\mathrm{t} /$ ha.year $)$,

SDR = sediment delivery ratio,

$\mathrm{R}=$ rainfall erosivity $(\mathrm{MJ} . \mathrm{mm} / \mathrm{ha} . \mathrm{h})$,

$\mathrm{K} \quad=$ soil erodibility

(t.ha.h/ha.MJ.mm),

LS = topographic factor (dimensionless),

$\mathrm{CP}=$ vegetation cover and conservation practice factor (dimensionless).

\section{RESULTS AND DISCUSSION}

The summary results of the study on the prediction of sediment yields from the Dodoma District catchments (Imagi, Matumbulu, and Msalatu) are shown in Table 1. The measured sediment yield values were extracted from the research work by Christiansson (1981). The values do not include suspended solids that left the storage reservoirs through spillways in times of floods.

Rainfall in semi-arid Tanzania is very eratic. During the period of sediment yield measurements annual rainfall in the study area varied from 174 $\mathrm{mm}$ (Matumbulu catchment) to $1114 \mathrm{~mm}$ (at Dodoma Airport). These variations in rainfall resulted in large variations of calculated annual rainfall erosivity ranging from 187 (MJ.mm/ha.h.y) to 5463 (MJ.mm/ha.h.y). These erosivity variations are also reflected in the average annual rainfall erosivity values shown in Table1 for the different sediment measurement periods in the three catchments, which ranged from 1645 MJ.mm/ha.h.y for Matumbulu catchment to 2706 MJ.mm/ha.h.y for Msalatu catchment.

The soil erodibility values ranged from 0.009 t.ha/ha.MJ.mm for the brown sands derived from granitic rock to 0.053 t.ha/ha.MJ. mm for loam and sand clay loam soils derived from colluvial materials in the valley bottoms.However, the overall soil erodibility averages for the three catchments were the same as shown in the results. Generally the soils in the catchments on eroding slopes are of low erodibility, i.e. not more than 0.013 t.ha./ha.MJ.mm. Thus, high soil erosion rates result from high rainfall erosivities and inappropriate land resources use as the dominating topography in the study area is undulating plains.

The slope gradients and lengths calculated using equations 3 and 5 were $9.5 \%$ and $345 \mathrm{~m}, 11.88 \%$ and $256 \mathrm{~m}$, and $7.13 \%$ and $166 \mathrm{~m}$ for Imagi catchment, Matumbulu catchment, and Msalatu catchment respectively. These are characteristics of the catchments as they generally represent upper segments of larger drainage basins. These catchments' topographic parameters were used to determine the sediment yield model's topographic factors for the catchments as shown in table 1. 
Table 1: Measured reservoir sediments and sediment yield modeling results for the Imagi, Matumbulu and Msalatu Catchments in Dodoma, central Tanzania

\begin{tabular}{|c|c|c|c|c|c|c|c|}
\hline \multirow{2}{*}{$\begin{array}{l}\text { Catchment/P } \\
\text { eriod }\end{array}$} & \multirow{2}{*}{$\begin{array}{l}\text { Measured } \\
\text { sediments } \\
(\mathrm{t} / \mathrm{ha} / \mathrm{y})\end{array}$} & \multicolumn{5}{|c|}{ USLE Factors } & \multirow{2}{*}{$\begin{array}{l}\text { Predicted } \\
\text { Sediments } \\
\text { (t/ha.y) }\end{array}$} \\
\hline & & $\begin{array}{c}\mathrm{R} \\
(\mathrm{SI})\end{array}$ & $\begin{array}{c}\mathrm{K} \\
\text { (SI) }\end{array}$ & SL & $\mathrm{C}$ & SDR & \\
\hline $\begin{array}{r}\text { Imagi } \\
1934-50 \\
1950-60 \\
1960-71 \\
1934-71\end{array}$ & $\begin{array}{l}7.455 \\
11.25 \\
9.3 \\
9.0\end{array}$ & $\begin{array}{l}2558 \\
2419 \\
2320 \\
2519\end{array}$ & $\begin{array}{l}0.012 \\
0.012 \\
0.012 \\
0.012\end{array}$ & $\begin{array}{l}5.03 \\
5.03 \\
5.03 \\
5.03\end{array}$ & $\begin{array}{l}0.07 \\
0.15 \\
0.15 \\
0.11\end{array}$ & $\begin{array}{l}55 \\
55 \\
55 \\
55\end{array}$ & $\begin{array}{l}5.946 \\
12.048 \\
11.555 \\
9.535\end{array}$ \\
\hline $\begin{array}{l}\text { Matumbulu } \\
1962-71 \\
1971-74 \\
1962-74\end{array}$ & $\begin{array}{l}9.39 \\
6.68 \\
8.72\end{array}$ & $\begin{array}{l}2046 \\
1645 \\
1946\end{array}$ & $\begin{array}{l}0.012 \\
0.012 \\
0.012\end{array}$ & $\begin{array}{l}6.27 \\
6.27 \\
6.27\end{array}$ & $\begin{array}{l}0.15 \\
0.15 \\
0.15\end{array}$ & $\begin{array}{l}42 \\
42 \\
42\end{array}$ & $\begin{array}{l}9.697 \\
7.796 \\
9.223\end{array}$ \\
\hline $\begin{array}{l}\text { Msalatu } \\
1944-50 \\
1950-60 \\
1960-71 \\
1971-74 \\
1944-74\end{array}$ & $\begin{array}{l}9.1 \\
6.9 \\
9.6 \\
8.2 \\
8.5\end{array}$ & $\begin{array}{l}2706 \\
2419 \\
2320 \\
2587 \\
2476\end{array}$ & $\begin{array}{l}0.012 \\
0.012 \\
0.012 \\
0.012 \\
0.012\end{array}$ & $\begin{array}{l}2.22 \\
2.22 \\
2.22 \\
2.22 \\
2.22\end{array}$ & $\begin{array}{l}0.21 \\
0.16 \\
0.25 \\
0.25 \\
0.21\end{array}$ & $\begin{array}{l}47 \\
47 \\
47 \\
47 \\
47\end{array}$ & $\begin{array}{l}7.115 \\
4.846 \\
7.262 \\
8.098 \\
6.51\end{array}$ \\
\hline
\end{tabular}

The plant cover and management factor $(\mathrm{C})$ varied from $0.01(0.02)$ on inselberg slopes not open to grazing and having dense vegetation cover of greater or equal to $75 \%$ to $0.6(0.75)$ for cultivated fields (and grazed during the dry seasons). The factor calculations using the subfactor method (Dissmeyer,1982) resulted in C values of 0.17 on heavily grazed areas with estimated plant cover of $20 \%$ (Stocking et al., 1988). This was obtained by multiplication of cover factor (0.6), surface roughness factor $(0.8)$, fine root factor $(0.8)$, and reconsolidation factor $(0.45)$.

The results show that much of the sediment yield variations were influenced by the rainfall erosivity (R) values, plant and land management factor(C) values, and the topographic factor (SL) values. This is in agreement with the conclusion reached by Stocking and associates (1988) that the principal determinant of specific rates of soil erosion is vegetation cover and that lack of vegetation results in incidences of very high erosion rates. They also observed that the rates of erosion may well be determined as much by rainfall erosivity, soil erodibility, and slope where cover is good (60 to $100 \%$ ).

The results show that some of the predicted sediment yields were less than the measured values while some others were higher or more - or- less equal to the measured values. Since the measured values do not include sediments leaving the reservoirs through spillways during floods, the predicted values were expected to be relatively higher than the measured ones. But it should be noted that small proportions of clay sized particles which do not settle easily under very low flow conditions that existed in the reservoirs left through overflows, thus the measured sediments values in the reservoirs are close to actual sediments yields from the catchments.

The predicted sediment yields have good correlation with the measured sediments as shown in Fig. 2. Measured sediment yields range from about $7 \mathrm{t} /$ ha.year to $11 \mathrm{t} /$ ha.year, while the predicted sediments range from about $6 \mathrm{t} / \mathrm{ha}$.year to 12 $\mathrm{t} /$ ha.year and have good correlation, with coefficent of determination $\left(\mathrm{R}^{2}\right)$ equal to about 0.53 . Given that the use of USLE employs many environment statistical parameters (SDR, rainfall erosivity, soil erodibility, plant cover and management) the results are quite reasonable and the equation has shown to be a useful tool even under conditions of limited data like Tanzania. The results have the expected accuracy given that the SDRs are highly variable for given catchment areas and rainfall erosivity values calculated using Moore's (1979) equation are acceptable where more accurate estimates are missing. Furthermore, cover and management factors were estimated based on general plant cover and ground surface condition information and not actual measured values for given tracts of land. 


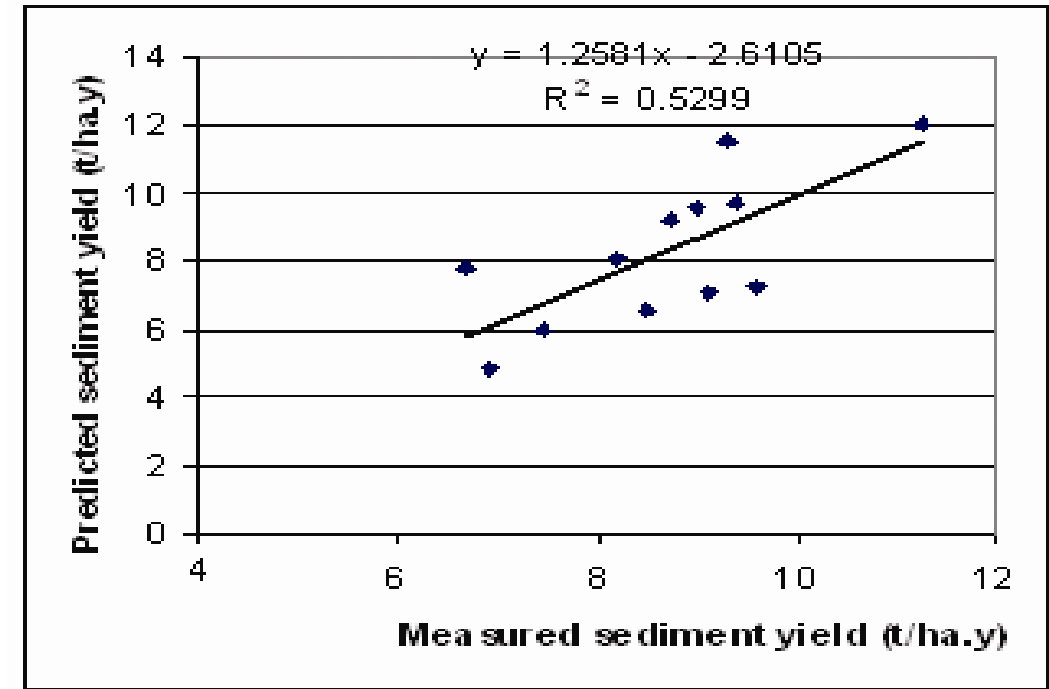

Fig. 2: Measured and predicted annual sediment yields for Imagi, Matumbulu, and Msalatu Catchments near Dodoma city, Tanzania

Prediction of sediment yields from catchments is very important where water resources sedimentation is a serious problem like Tanzania and construction of dams is needed. Had sediment yield modeling been used before the construction of the three Dodoma reservoirs (Imagi, Matumbulu, and Msalatu) and many others, misuse of the financial resources committed to the projects would have been avoided. Soil and water conservation planning to keep down soil erosion in catchments could have also been part of the reservoirs development.

\subsection{SUMMARY, CONCLUSIONS AND RECOMMENDATION}

Soil erosion and sedimentation is serious and is resulting in rapid sedimentation of streams and reservoirs. This makes sediment yield modeling important before any water storage dams construction projects can be undertaken. At present sediment yield prediction can be done using physically based models, empirical soil erosion models, and sediment rating curves. The physically based models contain numerous parameters that are difficult to measure or estimate, making them inapplicable in most of the developing countries; Tanzania inclusive. The rating curves give rough estimates that are not suitable for planning water resources development projects. Among many empirical models, the revised USLE was identified to be appropriate for predicting sediment yields by transforming whole catchments to plot equivalent areas and finally coupling the model with sediment delivery ratios (SDRs) determined for specific catchments based on their areas.
Testing of the model on the three Dodoma catchments in semi-arid central Tanzania has shown to give acceptable results. The measured sediment yields and the predicted sediments have good correlation, with coefficent of determination $\left(R^{2}\right)$ equal to about 0.53 . Since soil erosion and sedimentation of water resources are serious problems in Tanzania, sediment yield modeling using the RUSLE can be a very useful tool in the country.

\section{REFERENCES}

Al Kadhimi, A. M. H., 1982. Land use, water yield and soil erosion: Simulation of cause and effect.PhD thesis, Univ. of Strathclyde, Scotland, $363 \mathrm{pp}$.

Christiansson, C., (1981). Soil erosion and sedimentation in semi-arid Tanzania: Studies of environmental change and ecological imbalance. Scandinavian Inst. African Studies, Uppsala and Depart of Phy. Geogr., Univ. of Stockholm, 208 pp.

De Pauw, E.; Magogo J. P., and Niemeyer, J., (1983). Soil survey report of Dodoma Capital City District. Nationam Soil Service, Mlingano, Tanga, Tanzania. Soil Survey Report No. 4. URT Report, FAO/UNDP, 127 pp.

Dissmeyer, G. E., (1982). Developing a USLE cover-management (C) factor procedure for forest conditions. In Proc. Of workshop on estimating soil erosion and sediment yield on 
rangelands. USDA, ARS, Washington DC ARM-W-26:166-187.

Elwell H. A., and Stocking, M. A., (1982). Developing a simple yet practical method of soil loss estimation. Tropical Agriculture (Trinidad) 59:43-48.

Ferro, V.; Bagarello, V.; Di Stefano, C.; Giordano, G., and Parto, P., (2001). Monitoring and predicting sediment yield in small Sicilian basin. Trans. ASAE, Vol. 44(3): $485-595$.

Liu, B. Y.; Nearing, M. A., and Risse, L. M., (1994). Slope gradient effects on soil loss for steep slopes. Trans. ASAE, Vol.37(6): 1835 1840 .

McCool, D. K.; Foster, G. R.; Mutchler, C. K., and Meyer, L. D., (1989). Revised slope length factor for the Universal Soil Loss Equation. Trans. ASAE Vol.32(5):1571 1576.

Moore, T. R., (1979). Rainfall erosivity in East Africa. Geografiska Annaler, 61A, 3 - 4:147 -156 .

Morgan, R. P. C., (1986). Soil erosion and conservation, Longman, $298 \mathrm{pp}$.

Morgan, R. P. C., (1994). The European soil erosion model: An update on its structure and research base. In: R. J. Rickson (Ed) Conserving soil resources, European perspectives. CAB Intern., Wallingford, Oxfordshire: $286-299$.

Mulengera, M. K., (1996). Soil loss prediction in the semi-arid Tropical savanna zone: A tool for soil conservation planning in Tanzania. PhD thesis, Univ. of Newcastle upon Tyne, $231 \mathrm{pp}$.

Mulengera, M. K., and Payton, R. W., (1999). Estimating the USLE - soil erodibility factor in developing tropical countries. Trop. Agric. (Trinidad) Vol. 76 No. 1:17 - 22.

Murray-Rust, D. H., (1972). Soil erosion and reservoir sedimentation in a grazing area west of Arusha, northen Tanzania. Geogr. Ann., Vol. 54 A (3-4): 325 - 343.

Rapp, A., Axelsson, V., Berry, L., and MurrayRust, D. H., (1972). Soil erosion and sediment transport in the Morogoro river catchment, Tanzania. Geogr. Ann., Vol. 54 A (3-4):125 - 155 .

Renard K. G., Foster, G. R., Weesies, G. A., and Porter, J. P., (1991). RUSLE: Revised universal soil loss equation. J. Soil \& Water Conservation: $30-33$.

Stocking, M. A.; Chekela, Q., and Elwell, H. A., (1988). An improved method for erosion hazard mapping part1: The technique. Geografiska Annaler 70A, 3:169 - 180.

Temple, P.H., and Sundborg, A., (1973). The Rufiji river, Tanzania: Hydrology and sediment transport.BRULUP, Research Monograph No.1, Univ. of Dar es Salaam: $345-368$

Walling, D. E., (1988). Measuring sediment yield from river basins. In: Lal, R. (Ed) Soil erosion Research Methods. SWCS, Ankeny, Iowa: $39-74$.

Williams, J. R., (1975). Sediment yield prediction with universal equation using runoff energy factor. In: Present and prospective technology for predicting sediment yields and sources. ARS-S-40,USDA, Agrc. Res. Ser.:244 - 253.

Williams, J. R., and Berndt, H. D., (1977). Sediment yield prediction based on watershed hydrology. Trans. ASAE Vol. 20(6):11001104.

Williams, J. R., and Berndt, H. D., (1972). Sediment yield computed with universal equation. J. Hydr. Div., ASCE 98 (HY 12): $2087-2098$.

Wishmeier, W. H., and Smith, D. D., (1978). Predicting rainfall erosion losses $-\mathrm{A}$ guide to conservation planning. USDA, Agric. Handbook No. 537, 58pp. 